\title{
Post-Olympic Use of the Olympic Venues: The Case of Greece
}

\author{
By Evangelia Kasimati ${ }^{* 1}$
}

The 2004 Athens Olympic Games provided the host city with a unique challenge to ensure long-term benefits and to present itself worldwide as a modern, well designed and well run metropolis with infrastructure and state-of-the-art facilities, promoting the quality of life for its residents, as well as its economic and cultural development. The way however that the huge and costly sports facilities, unanimously acknowledged as a burden on the national economy and the Greek taxpayers, were to be used and exploited after the Games, became a headache to all post-games governments. The post-Olympic era was largely characterised by the incapability of the government to productively utilize the extensive infrastructure of the Olympic games. The bureaucracy and the lack of governmental long-term planning, left most venues unexploited and abandoned right after the games. Hellenic Olympic Properties (HOP), a government-controlled company responsible for making use of each of the Olympic venues after the games was extremely slow and inefficient in the utilization of its assets, while its annual published financial statements revealed consistently negative bottom lines. Seven years after the games, the reality is that the expected benefits from the post-Olympic use of the facilities to the Greek economy still remain to be seen.

Keywords: Greece, Hellenic Olympic Properties, Olympic venues, Post-Olympic use.

\section{Introduction}

The modern Olympic Games were first held in Athens in 1896, with subsequent set of games held every four years thereafter. Over the years, the games have survived many trials, including wars and boycotts. In recent years, the interest of countries and regions in staging a future edition of the games has grown because of the perception that doing so would help attract tourists and generate income as well as improve the infrastructure of the host cities (Kasimati 2003). Countries spend significant amounts of money in bidding and, if successful, in constructing the infrastructure and stadia required to host such events. Economists, see Noll and Zimbalist (1997) and Siegfried and Zimbalist (2000) have argued that the economic evaluation of sports venues is weak which leads to an overestimation of the economic benefits and an underestimation of the overall costs in order to make an argument in favour of the project. Given the generally high costs associated with the Olympic games,

\footnotetext{
* Bank of Greece, Athens, Greece.

${ }^{1}$ The author's view expressed in this study does not necessarily reflect those of the Bank of Greece.
} 
the perception that host cities and surrounding regions benefit economically from these events has come under major scrutiny.

Greece's bid for the 2004 Olympic games was rewarded with success when, on $5^{\text {th }}$ September 1997, Juan Antonio Samaranch, President of the International Olympic Committee, announced that Athens would host the $28^{\text {th }}$ Olympic games. The announcement of this positive development, following an unsuccessful bid to host the 1996 Olympics, inspired the Greek public to welcome sports to the top of the national agenda and to highlight their benefits. On the other hand, however, there were complaints about the enormous drain on the public funds that such a large scale event would entail (Kissoudi 2010).

Greece was the smallest country to stage the Summer Olympics since Finland in 1952 and the organisers faced the challenge of delivering all the facilities on time and in line with the required standards. The potential effect of the games on the Greek economy received some academic attention. Kasimati and Dawson (2009) found that the Olympic games appear to have had a positive impact on the Greek economy. In particular, by developing a small macroeconometric model of the Greek economy, they found that for the period 1997-2005 the games boosted economic activity by around 1.3 percent of GDP per year, while unemployment fell by 1.9 percent per year. The cumulative GDP increase attributed to the games over the period 1997-2005 was estimated to be 2.5 times the total preparation cost. Veraros et al. (2004) found a positive and statistically significant impact on the Athens Stock Exchange following the announcement of the nomination of Athens to host the games on $5^{\text {th }}$ September 1997. Papanikos (1999) and Balfousia-Savva et al. (2001), through their impact assessment studies, calculated GDP growth of US\$10.1-15.9 billion, new tourist arrivals of 4.8-5.9 million and new job creations of 300-445 thousands.

The 2004 games provided Athens with an opportunity to acquire world class sporting venues as well as to accelerate the completion of major infrastructure upgrades in transportation, telecommunications and other sectors. In many ways this has led some commentators (e.g. Preuss 2004) to draw parallels with the Barcelona 1992 Olympics. The cost related to the construction of sporting facilities was estimated at Euro 3.0 billion (Galpin 2005). An additional amount of Euro 4.2 billion was invested in projects of transportation (Euro 1.2 billion), communication (Euro 1.2 billion), security of games (Euro 1.1 billion) and other infrastructure (Euro 0.7 billion). It was in November 2004 when the government announced that the games' aggregate cost topped to Euro 9 billion (Kasimati and Dawson 2009).

The post-games use of all above investments was a challenge to Greece. It was expected that the Athens Olympics would act as a catalyst promoting the modern sports and culture in Greece, thereby benefiting the national economy. As such, the exploitation of first the games' legacy and second the urban infrastructure developed, should be carefully planned and incorporated into a long-term strategy targeting the cultural and economic development that would have a beneficial impact on the country as a whole. Consequently, the benefits offered by the games, which would provide the Athenians with a unique opportunity to upgrade the city infrastructure and acquire new sports facilities 
to enjoy for years to come, should certainly outlast the two-week celebration. However, soon after the 2004 games, serious questions arose about the ability to extract real benefit out of the Olympic facilities. Seven years later Athens post-Olympic facilities are still vacant, promised parks never materialized and new transportation infrastructure has caused problems like flooding and increased traffic.

In the present context we focus on examining i) the post-games use of the Greek Olympic venues, and ii) whether there was a long-term strategy for utilising each of them after the games. For this purpose, the paper is developed as follows: Next section discusses the new sports facilities and the urban infrastructure developed for the Athens Olympics. Subsequently, it examines the post-Olympic use of the precious Olympic legacy and presents key measurements of the economic and financial performance of Hellenic Olympic Properties (HOP), the government-controlled company, responsible for utilising each of the Olympic venues after the games. Finally, the paper reports our conclusions and spells out certain policy implications.

The importance and originality of this paper is founded on the argument that a post-Olympic research of the use of the Athens sports venues has not been done before. We hope that we offer a fair picture of the use and exploitation of the post-Olympic facilities and assets. We believe that this paper will be of interest to economists as well as to the researchers of the impact of the Olympic games, while our outcomes may also improve the information available to policy makers and potential future hosts of mega sporting events.

\section{Athens Summer Olympics: New Sports Facilities and Urban Infrastructure}

Whether a city is suitable as a host city for the games depends primarily on the amount of investments required to bring it up to Olympic standards and on the extent to which these investments are in line with the urban development concepts of the city in question. Given the size and magnitude of the event, Athens could use the opportunity to accelerate its modernization and briskly increase the pace of economic development. The 2004 Olympic games was expected to offer a unique opportunity for the acquisition of world class sports facilities, the regeneration of the city centre and outlying districts, the creation of a modern transport infrastructure and the implementation of projects for the protection of the environment (Synadinos 2004). To fulfil these expectations a building boom was initiated with the intention of creating impressive facilities spread around metropolitan Athens.

Table 1 reveals the bulk of sports venues that were built and renovated in Athens and other co-host cities. While the government took the responsibility for the construction of the sports venues for the games, their funding was a public and private sector undertaking. The costs associated with the sports venues were estimated to be around Euro 3 billion: approximately Euro 962 million financed by the private sector; Euro 1,800 million by the Greek 
government; and Euro 242 million from the organising Olympic committee (Kasimati 2008).

Table 1. List of the 2004 Olympic Games Venues

\begin{tabular}{|c|c|c|c|}
\hline Venues & Capacity & Type of Work & Euro mn \\
\hline $\begin{array}{l}\text { NON COMPETITION } \\
\text { VENUES }\end{array}$ & Beds & & \\
\hline $\begin{array}{l}\text { International Broadcasting } \\
\text { Centre (IBC) }\end{array}$ & & New Construction & 113.2 \\
\hline Main Media Centre (MPC) & & New Construction & 42.9 \\
\hline Olympic Village & 16,000 & New Construction & 287.9 \\
\hline Media Villages (9 locations) & 10,000 & New construction & \\
\hline COMPETITION VENUES & Seats & & \\
\hline $\begin{array}{l}\text { Athens Olympic Sports Complex } \\
\text { (OAKA) }\end{array}$ & & & \\
\hline Calatrava I \& II & & Aesthetic Renovation & 212.8 \\
\hline Olympic Stadium & 72,000 & Renovation & 18.4 \\
\hline Indoor Hall & 18,000 & & \\
\hline Tennis Centre & 20,000 & Renovation \& New & 31.2 \\
\hline Aquatic Centre & 22,500 & Renovation & 13.0 \\
\hline Velodrome & 5,000 & Renovation & \\
\hline Hellinikon Olympic Complex & & & \\
\hline Baseball Centre & 19,000 & New Construction & \\
\hline Softball Stadium & 5,000 & New Construction & \\
\hline Hockey Centre & 20,000 & New Construction & \\
\hline Indoor Halls & & \multirow{3}{*}{ New Construction } & 117.0 \\
\hline - $\quad$ Basketball & 15,000 & & \\
\hline - $\quad$ Fencing \& Wrestling & 8,500 & & \\
\hline Canoe/Kayak Slalom Centre & 5,000 & New Construction & 10.5 \\
\hline \multicolumn{4}{|l|}{$\begin{array}{l}\text { Faliro Coastal Zone Olympic } \\
\text { Complex }\end{array}$} \\
\hline $\begin{array}{l}\text { Peace \& Friendship Stadium } \\
\text { (SEF) }\end{array}$ & 14,000 & Renovation & 15.9 \\
\hline Sports Pavilion & 4,000 & New Construction & 208.0 \\
\hline Beach Volleyball Centre & 10,000 & New Construction & \\
\hline Subtotal & 264,000 & & $1,070.8$ \\
\hline Venues & Capacity & Type of Work & Euro mn \\
\hline \multicolumn{4}{|l|}{ GOUDI } \\
\hline Modern Pentathlon Centre & & \multirow{5}{*}{ Renovation \& Temporary } & \\
\hline - $\quad$ Fencing \& Shooting & 4,500 & & \\
\hline - $\quad$ Swimming & 2,000 & & 44.0 \\
\hline - $\quad$ Riding \& Running & 5,000 & & \\
\hline - $\quad$ Badminton & 5,000 & & \\
\hline
\end{tabular}




\begin{tabular}{|c|c|c|c|}
\hline MARKOPOULO & & & \\
\hline Shooting Centre & 8,000 & New Construction & 42.8 \\
\hline Equestrian Centre & 31,250 & New Construction & 181.4 \\
\hline \multicolumn{4}{|l|}{ FOOTBALL COURTS } \\
\hline Karaiskaki stadium, Athens & 33,000 & Renovation \& New & \\
\hline $\begin{array}{c}\text { Pampeloponnisiako Stadium, } \\
\text { Patra }\end{array}$ & 20,000 & Renovation & 26.4 \\
\hline Panathessaliko Stadium, Volos & 22,700 & Renovation \& New & 42.2 \\
\hline $\begin{array}{l}\text { Kaftantzoglio Stadium, } \\
\text { Thessaloniki }\end{array}$ & 22,700 & Renovation & 38.9 \\
\hline Pankritio Stadium, Heraklio & 26,400 & New Construction & 41.2 \\
\hline \multicolumn{4}{|l|}{ OTHER VENUES } \\
\hline $\begin{array}{l}\text { Panathinaiko Stadium } \\
\text { (Kallimarmaro) }\end{array}$ & 45,000 & Renovation & 2.6 \\
\hline Agios Kosmas Sailing Centre & 3,000 & New \& Temporary & 105.6 \\
\hline Vouliagmeni Triathlon Centre & 3,000 & Temporary & \\
\hline $\begin{array}{l}\text { Schinias Rowing/Canoeing } \\
\text { Centre }\end{array}$ & 24,000 & New Construction & 80.1 \\
\hline Peristeri Boxing Hall & 8,000 & Renovation & \\
\hline Nikaia Weightlifting Hall & 5,000 & New Construction & 32.5 \\
\hline Ano Liossia Olympic Hall & 9,400 & New Construction & 58.5 \\
\hline Galatsi Olympic Hall & 6,000 & New Construction & 42.6 \\
\hline Subtotal & 283,950 & & 738.8 \\
\hline TOTAL & $\mathbf{5 4 7 , 9 5 0}$ & & $1,809.6 *$ \\
\hline
\end{tabular}

Note: *According to Galpin (2005) the construction work for the venues cost around Euro 3.0 bn. Source: Kasimati 2008.

Out of the venues completed with a view of a post-games use, the Olympic Village is of the most interesting to discuss. With the exception of the 1984 Los Angeles Olympics and the 1996 Atlanta Olympic Games, when athletes and sports representatives were accommodated in the student residences of UCLA and Georgia Tech respectively, from 1932 onwards (when, for the first time, the host city of Los Angeles constructed a complex of houses for the athletes' accommodation) the Olympic Village has been part of a long-term business plan. In designing the Olympic Village, Athens aspired to create a modern urban area that might both solve environmental problems and meet housing needs. Built at the foot of Parnitha mountain, the village was intended to accommodate 16,000 athletes during the Olympic games and 6,000 athletes participating in the Paralympics.

Other interesting venues included the Media Village, intended to accommodate media and press representatives, and the International Broadcasting Centre (IBC), heart of the games' global television transmission, designed as an impressive modern building. 
New sports facilities and regeneration of the old ones were expected to encourage sports and promote Greece's image at international level. Of the existing sports facilities, the Olympic Sports Centre included the Olympic Stadium with a seating capacity of 72,000 spectators. The renovated stadium would host track and field events as well as the opening and closing ceremonies of the games. The Olympic Sports Centre also contained a small sporting hall and outbuildings, an aquatic centre (seating 22,500 spectators), a velodrome with seating capacity of 5,000 people, a big sporting hall (seating 16,000 spectators) and a tennis court which could accommodate 20,000 spectators. The development project for the Faliro area involved construction of the Sports Pavilion (Tae-Kwon-Do Hall), a modern building of about 4,000 retractable seats (an ideal place for conferences, concerts, commercial exhibitions and film productions in post-Olympic use), as well as the creation of an aquarium, a modern marina, the Olympic beach volleyball courts, an open-air theatre, pedestrian streets and an esplanade.

The Schinias Rowing and Canoeing Centre was part of an ambitious environmental and ecological project with the view of protecting the natural springs and the attractive landscape of the area. In addition, a series of projects to be built in deprived and downgraded areas were expected to improve the area by promoting tourism and culture, affording local people the opportunity of being involved in sports activities and providing employment. Such projects included the Agios Kosmas Sailing Centre, the Nikea Weightlifting Centre, the Markopoulo Shooting and Equestrian Centre, the Ano Liossia Centre, the Peristeri Boxing Hall and the Galatsi Hall.

The preparation project also involved regeneration of the Hellinikon Olympic Complex, site of the old Athens airport where, after renovation, the Olympic fencing, basketball, baseball and softball competitions were to take place. The Canoe Kayak Slalom, an impressive artificial lake of 2,250 meters in length with an auxiliary lake for the athletes' training and warm-up, canals and bridge, was added to the area. The long catalogue of sports facilities also included the Goudi Olympic Centre, a spacious hall for badminton, the restored equestrian centre and two open-air venues.

In addition, a large program of infrastructure works and industry development projects (a new airport, metro, tram, suburban railway, motorway system and upgraded road network) took place in the greater Athens area, part of this was funded through the Community Support Framework (CSF) of the European Union for the general improvement of the city's infrastructure, while the remainder was specifically developed for the needs of the games. Athens had many of the common disadvantages of a large city, such as haphazard developed residential areas on the outskirts, obsolete infrastructure, traffic congestion and environmental pollution resulting from rapid and unregulated construction growth in the 1950s, 1960s and 1970s, when extensive internal immigration to the city took place. Making use of the experience gained by large cities which hosted the Olympic games in the 1990s, Athens put into practice an ambitious regeneration plan, carried out by the Ministries of Culture and Environment, Physical Planning and Public Works, the 
Municipality of Athens, the Prefecture of Athens and Piraeus, the Technical Guild of Greece, the National Tourism Organisation and the Unification of the Archaeological Sites of Athens SA. All of this was coordinated by the 2004 organising Olympic committee (Beriatos and Gospodini 2004). Figure 1 shows a map of venues conveying the extent of exposure in sporting and non-games infrastructure. Spectators were able to commute using the Olympic Transport System, which consisted of the Metro, Tram, Suburban Rail and Buses. These systems formed an extensive public transport network that covered all the Olympic venues and events.

Figure 1. Map of the Olympic Venues and Events Hosted

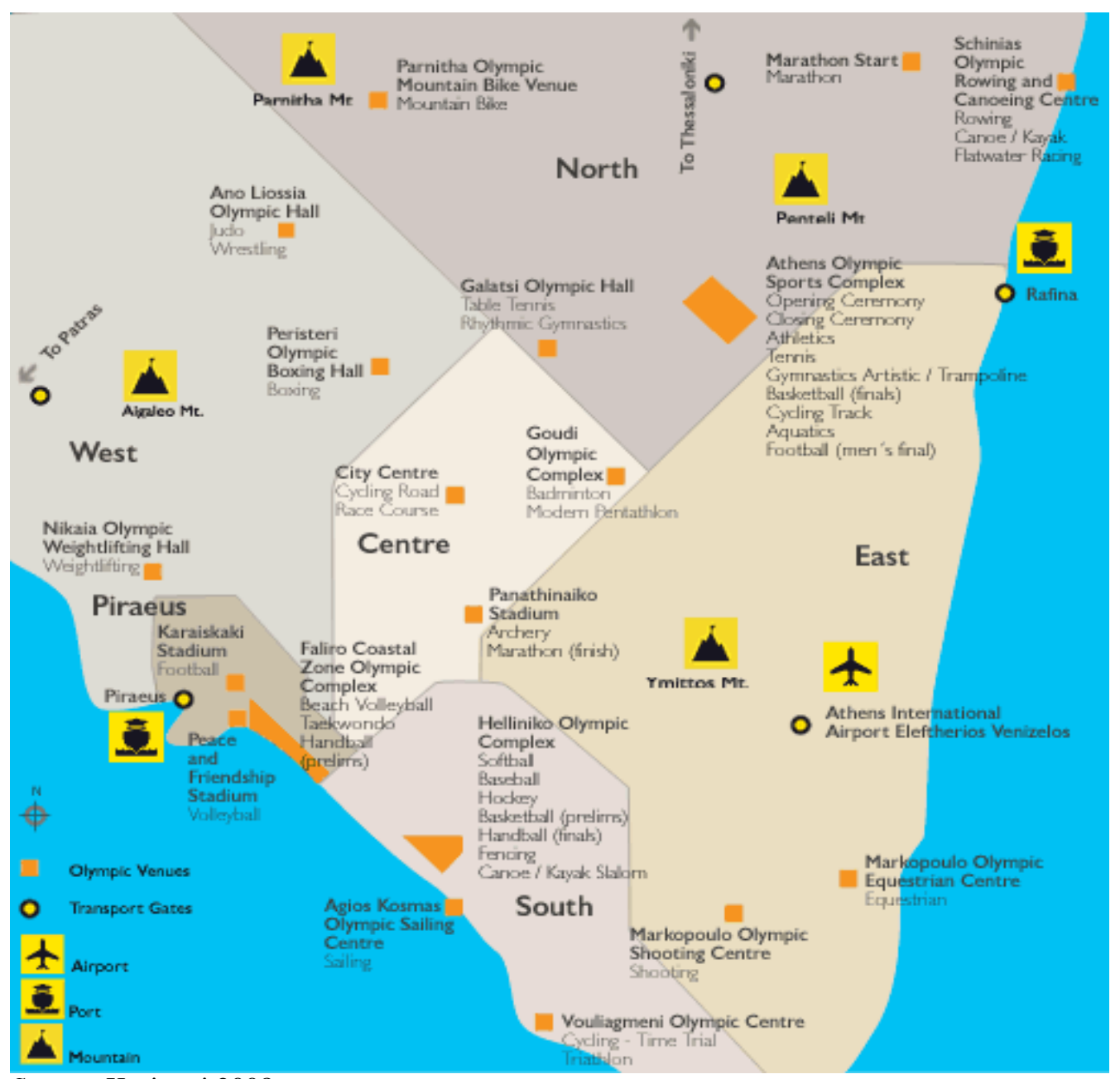

Source: Kasimati 2008.

Following the principle that construction works and innovative designs can give a new look to the host city and improve the quality of life, the project of the urban regeneration of Athens included construction works and the implementation of innovative designs and non-sporting projects. These included building works intended to renovate the historic centre of Athens by creating a zone of walkways that would unite the archaeological sites of the city. The restoration of monuments and open spaces, the reconstruction of 
streets and squares in the historic city centre and the renovation of neoclassicalstyle buildings were included in the ambitious plan (Kissoudi 2008). Pioneering architectural designs of international reputation were appraised as innovative, such as those submitted by the architect Santiago Calatrava. Modern designs selected by national and international competition and published architectural designs that presented new style trends were also regarded as innovative. The non-sporting projects involved construction works for the improvement of the transport infrastructure such as new roads and junctions, new metro lines and a tram network, along with enhancement of the existing public open spaces, removal of advertising panels and billboards from building facades and facade renovation of modern buildings in the city centre (Beriatos and Gospodini 2004).

The most important construction plan was the creation of a modern transport infrastructure so that crucial problems of traffic congestion could be eased. Athens, a congested city with approximately five million inhabitants, witnessed a speedy increase in car ownership at a rate of 350 cars per 1,000 citizens, while only 30 percent of the inhabitants made daily use of public transport. For this reason, a large number of construction projects in the "transportation" chapter of the 2004 candidacy file aspired to improve transport infrastructure and ease traffic flow (Frantzeskakis and Frantzeskakis 2006). Thus the extension of the Athens Metro, the modernization of the existing public transport system, the implementation of a new tram line linking the city centre to the waterfront, the provision of motorways and slip roads to provide speedy and safe access to Athens International Airport as well as the creation of footpaths linking major attractions in the city centre were considered crucial to the improvement of the quality of life. Moreover, since thousands of athletes, team escorts, judges, referees, media and press representatives, spectators, employees and volunteers were expected to travel to the Olympic facilities on a daily basis, road and railway network improvement was regarded as crucial to the success of the games (Kissoudi 2008).

The 2004 Olympic games acted as a catalyst for the urban development of Athens and accelerated changes that may otherwise have taken many years to be completed. A public opinion poll held during the period 21 February 2003 to 10 January 2004 revealed that the Greek people felt proud of the games and supported them despite the huge cost. The feelings of pride and support for the games were comparable among people of different ages and political ideologies and this strengthened the perception that there was a strong relationship between the Olympic games and national pride.

\section{The Post-Olympic Use of the Greek Olympic Venues}

As soon as the games were over, a special legal framework for the future use of all Olympic facilities was formulated and enacted via law in 2005 (Hellenic Government Gazette 2005). Apart from the uses allowed for hosting the games the following functions and uses were allowed per category of 
venue. Within basketball and fencing venues, cultural events, exhibitions, commercial shops and food courts were allowed. Within baseball, softball and hockey venues, athletic uses, cultural events and assemblage public domains were allowed. Within the existing installations of the canoe-kayak-slalom venue, shops selling or renting sports gear and assemblage public domains were permitted, while in the surrounding areas a theme (sports) park and a hydro park were also permitted (Milionis 2010). HOP, a management authority established exactly for the purpose of securing the post-Olympic use of most of the Olympic properties was also legislated via the same legal framework.

On the day of the opening ceremony of the Beijing 2008 games the newspaper Kathimerini reported that:

...as soon as the Athens Games were over, it was clear that without the International Olympic Committee's incessant carping and with Greeks no longer needing to display their best face to the world, there was no plan for the day after. Apart from the major transportation projects that have transformed the city, the purely Olympic projects were left in limbo like the fossils of white elephants, the decaying abandoned reminders of a collective dream that we could not translate into reality.

(Kathimerini 2008: 10)

Following criticism from the Greek and foreign press on neglected and underused venues, HOP hastened to publish various press releases reporting its progress in the utilization of the post-Olympic assets. Table 2 delineates the current or proposed status of the 2004 Summer Olympic facilities. 
Table 2. Post-Olympic Use of the Greek Olympic Venues

\begin{tabular}{|c|c|c|}
\hline Facility & Olympics Use & Current/Proposed Use \\
\hline $\begin{array}{l}\text { International Broadcasting } \\
\text { Centre (IBC) }\end{array}$ & $\begin{array}{c}\text { International Broadcast } \\
\text { Centre }\end{array}$ & $\begin{array}{l}\text { Was leased to the private company Lamda Development SA in August } 2006 \text { and has been } \\
\text { converted to a shopping, retail, office and entertainment complex known as the "Golden Hall". } \\
\text { Will also become home to the Hellenic Olympic Museum and the International Museum of } \\
\text { Classical Athletics }\end{array}$ \\
\hline Main Press Ce & Main Press Centre & $\begin{array}{l}\text { Has been converted to the new headquarters of the Ministry of Health and Social Security, and } \\
\text { the amphitheatre contained within has hosted numerous ceremonies and public events }\end{array}$ \\
\hline Olym & $\bar{H}$ & $\begin{array}{l}2,292 \text { apartments were offered at a reduced price to low-income workers, beneficiaries of the } \\
\text { Workers' Housing Organisation. A modern town of about } 10,000 \text { residents was envisaged }\end{array}$ \\
\hline $\begin{array}{l}\text { Athens Olympic Stadium } \\
\text { (OAKA) }\end{array}$ & $\begin{array}{c}\text { Opening \& Closing } \\
\text { Ceremonies, Track \& } \\
\text { Field, Football }\end{array}$ & $\begin{array}{l}\text { Home pitch for Panathinaikos FC, AEK FC (Football: Greek Super League, UEFA Champions } \\
\text { League), Greek national football team (some matches), International football competitions; } \\
\text { Track \& Field events (e.g. IAAF Athens Grand Prix), 2005 Eurovision Song Contest, Concerts }\end{array}$ \\
\hline $\begin{array}{l}\text { Helli } \\
\text { Aren }\end{array}$ & Basketball, Handball & Home court for Panionios BC (basketball), Conventions and trade shows \\
\hline $\begin{array}{l}\text { Hellinikon Canoe/Kayak } \\
\text { Slalom Centre }\end{array}$ & $\mathrm{ak}$ & $\begin{array}{l}\text { Turned over to a private consortium (J\&P AVAX, GEP, Corfu Waterparks and BIOTER), plans } \\
\text { to convert it to a water park }\end{array}$ \\
\hline $\begin{array}{l}\text { Hellinikon Olympic Hockey } \\
\text { Centre }\end{array}$ & Field Hockey & Mini-football, will be part of new Hellinikon metropolitan park complex \\
\hline Hellinikon Baseball Stadium & Baseball & $\begin{array}{l}\text { Converted to football pitch, home field of Ethnikos Piraeus F.C. (Football: Greek second } \\
\text { division) }\end{array}$ \\
\hline Hell & & \\
\hline $\begin{array}{l}\text { Agios Kosmas Olympic } \\
\text { Sailing Centre }\end{array}$ & Sailing & $\begin{array}{l}\text { Turned over to the private sector (Seirios AE), will become marina with } 1,000+\text { yacht capacity } \\
\text { and will be part of Athens' revitalized waterfront }\end{array}$ \\
\hline Ano Liosia Olympic Hall & Judo, Wrestling & $\begin{array}{l}\text { TV filming facility, Future home of the Hellenic Academy of Culture and Hellenic Digital } \\
\text { Archive }\end{array}$ \\
\hline Faliro Sports $\mathbf{P}$ & Handball, Taekwondo & $\begin{array}{l}\text { Converted to the Athens International Convention Centre, hosts conventions, trade shows and } \\
\text { concerts, such as a concert by the guitarist Gary Moore, the Todo Latino Salsa Festival and a } \\
\text { three-day international Salsa dance festival }\end{array}$ \\
\hline
\end{tabular}




\begin{tabular}{|l|c|l|}
\hline Galatsi Olympic Hall & $\begin{array}{c}\text { Table Tennis, } \\
\text { Rhythmic Gymnastics }\end{array}$ & $\begin{array}{l}\text { After 2004, was the home court of AEK BC (basketball) before the team moved to the Athens } \\
\text { Olympic Indoor Hall. Turned over to the private sector (Acropol Haragionis AE and Sonae } \\
\text { Sierra SGPS S.A), being converted to a shopping mall and retail/entertainment complex }\end{array}$ \\
\hline $\begin{array}{l}\text { Markopoulo Olympic } \\
\text { Equestrian Centre }\end{array}$ & Equestrian & Horse racing, Domestic and International Equestrian meets, Auto racing (rally) \\
\hline $\begin{array}{l}\text { Markopoulo Olympic } \\
\text { Shooting Centre }\end{array}$ & Shooting & Converted to the official shooting range and training centre of the Hellenic Police. \\
\hline $\begin{array}{l}\text { Nikaia Olympic Weightlifting } \\
\text { Hall }\end{array}$ & Weightlifting & $\begin{array}{l}\text { Has hosted fencing competitions in the years following the Olympics, but has recently been } \\
\text { turned over to the University of Piraeus for use as an academic lecture and conference centre. }\end{array}$ \\
\hline $\begin{array}{l}\text { Schinias Olympic Rowing and Rowing and Canoeing } \\
\text { Canoeing Centre }\end{array}$ & $\begin{array}{l}\text { One of only three FISA-approved training centres in the world, the others being in Munich and } \\
\text { Seville. Hosts domestic and international rowing and canoeing meets. Part of the Schinias } \\
\text { National Park, completely reconstructed by the German company Hochtief. }\end{array}$ \\
\hline Pagritio Stadium & Football & $\begin{array}{l}\text { Home pitch for OFI FC and Ergotelis FC (Football: Greek Super League). Hosted the 2005 } \\
\text { Greek football All-Star game. Also home to various track-and-field meets. }\end{array}$ \\
\hline
\end{tabular}

Source: Hellenic Olympic Properties 2006, 2008 \& Own elaboration. 
In short by 2010 a number of the post-Olympic assets are in either full or partial use, reconstruction work is in progress on some of the facilities, and a building work license is expected to be issued for some assets, while a number of sports facilities are leased on short-term contract or remain deserted and under guard, awaiting completion of international competition or deliberation. More significantly, disagreement and dispute between the municipal authorities and HOP resulted from the fact that the post-Olympic sports facilities were leased to businessmen to convert them into shopping centres and recreation places for their profit, while no particular provision for the protection of the environment was made (Kissoudi 2010).

\section{Economic and Financial Performance of HOP}

HOP, a government-controlled company under the control of the Ministries of Finance, National Economy and Culture, was assigned with the creation and implementation of a long-term strategy for utilizing each of the Olympic venues after the games. Established by Law in 2005, HOP was not a flawed realization of original intentions mentioned in the Athens Bid File in 1997, but an afterthought of the Greek state (Hellenic Government Gazette 2005).

HOP's strategy focused in ensuring sustainable urban and peripheral development by utilizing existing Olympic assets in line with national tourism policy goals and priorities. Its priority was to manage and administrate Olympic assets through modern forms of partnership, adhering to environmental protection principles, encouraging dialogue with local communities and employing modern financial tools which promote synergies between the public and the private sector. The right to administer, maintain and exploit the facilities (paying annual rent to the Greek state) would be given to the businessmen who made the bid. The value of the property that HOP was entrusted to administer amounted to Euro 2 billion, roughly 1.3 percent of the gross domestic national product, while, in a rough estimate, the cost of the facilities' maintenance after the games was expected to Euro 15 million per annum (Kissoudi 2008).

This section examines and analyses the economic and financial position of HOP. The methodology used incorporates basic accounting performance measures, in order to infer remarks and conclusions on HOP's financial position, capital structure and profitability. The data of this study are derived from the company's published annual financial statements for the years 20042009. The data source for this analysis is the ICAP database, as well as the company's official, before the merger, website www.olympicproperties.gr.

\section{HOP's Economic Position}

The turnover analysis is our starting point in the examination of HOP's economic position and provides useful insight into its profitability and 
liquidity. In its annual financial statements there is no turnover analysis or breakdown, since information is not provided regarding sources of income and any potential categorization. During the period 2004-2009 HOP's annual turnover presented an increasing trend with an average rate of 148 percent per annum, while its net economic effect was a loss of Euro 35.5 million, as reflected in Figure 2. Losses in the $\mathrm{P} \& \mathrm{~L}$ account may have impeded the company's ability to raise funds from the banking system or the stock exchange thus resulting to its merger with the Hellenic Tourist Properties.

Figure 2. Hellenic Olympic Properties: Turnover and EBT during 2004-2009

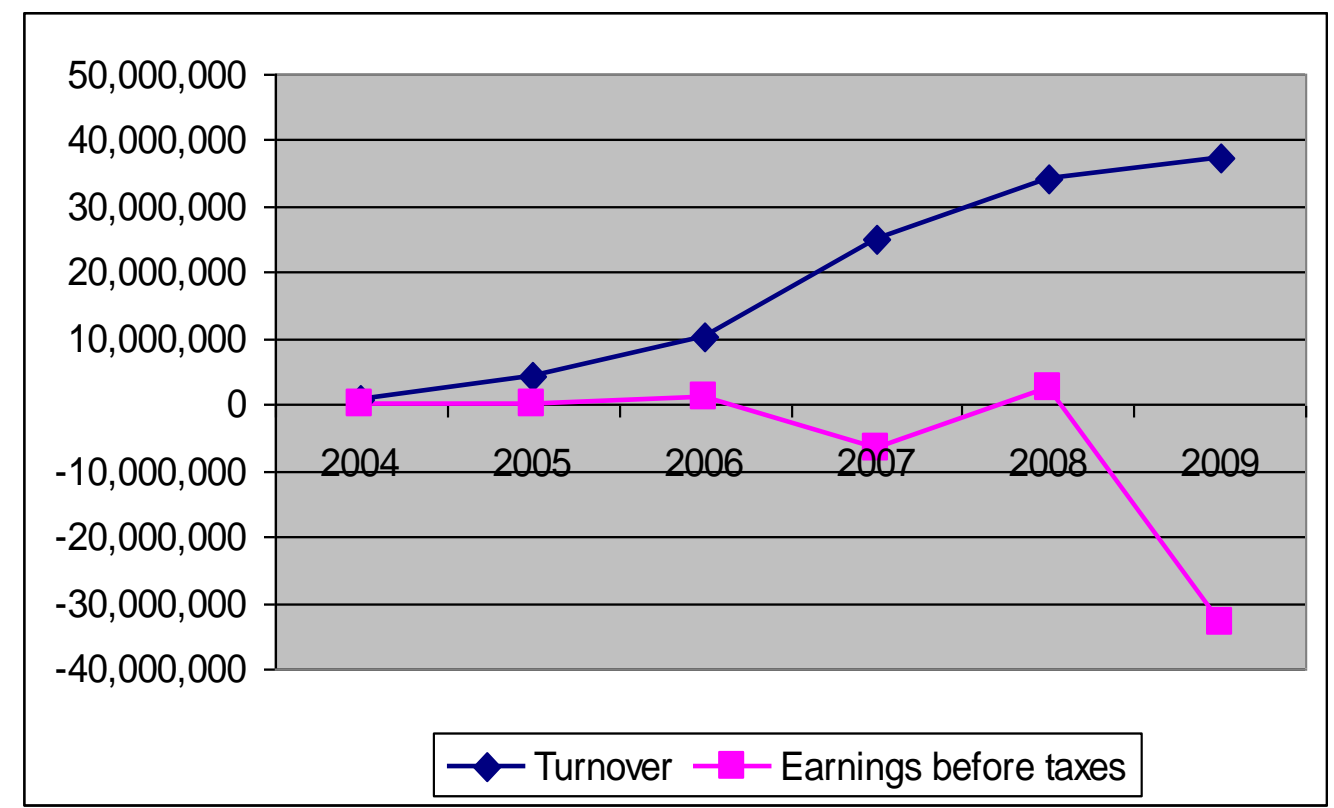

Source: Published Annual Financial Statements \& Own calculations.

Comparing HOP's total equity and liabilities during the period 2004-2009, we observe that the latter exceeds the equity by 9.8 times (Figure 3 ). Since the equity is exposed to greater risks than the debt funds, the government-the major shareholder- was the one that undertook most of the business risk that HOP faced. 
Figure 3. Hellenic Olympic Properties: Liabilities and Equity during 20042009

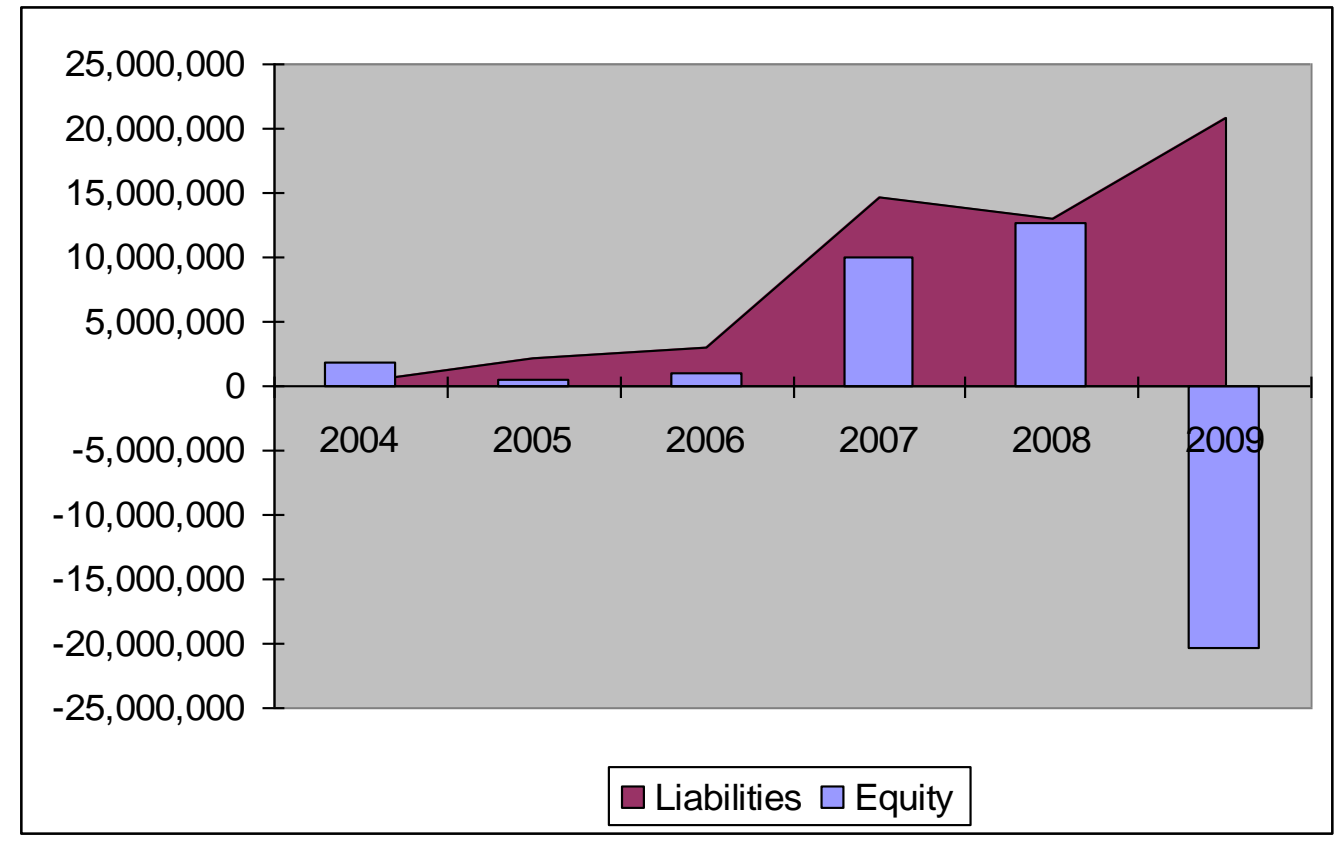

Source: Published Annual Financial Statements \& Own calculations.

HOP's Financial Performance: Analysis of Profitability, Liquidity and Financial Structure

The profitability ratios are arguably among the most important in business finance (Walsh, 2005). Companies with sound financial ratios experience less difficulties in attracting funds either from the banking sector or the capital markets (Weston and Brigham 1986).

In our profitability analysis, we study the gross profit margin, the earnings before interest, tax, depreciation and amortization (EBITDA) margin and the earnings before tax (EBT) margin. These are effectively three different profit measurements expressed as a percentage of the company's turnover. We also examine the Return on Equity (ROE) ratio, which measures the rate of return that HOP is delivering to the owners and is calculated as a percentage of earnings after tax to the average of total equity. Since HOP' assets include the Olympic venues, we also calculate the Return on Assets (ROA) ratio, which refers to earnings before interest and tax divided by the average of total assets. 
Table 3. HOP's Financial Performance

\begin{tabular}{|r|c|c|c|c|c|c|c|}
\hline Ratios & $\mathbf{2 0 0 4}$ & $\mathbf{2 0 0 5}$ & $\mathbf{2 0 0 6}$ & $\mathbf{2 0 0 7}$ & $\mathbf{2 0 0 8}$ & $\mathbf{2 0 0 9}$ & $\begin{array}{c}\text { Average } \\
\mathbf{2 0 0 4 - 2 0 0 9}\end{array}$ \\
\hline Profitability ratios (in \%) & & & & & & & \\
\hline Gross Profit Margin & 77.67 & 69.85 & 54.43 & 2.63 & 7.18 & 50.29 & 43.68 \\
\hline EBITDA Margin & 31.89 & 7.08 & 15.29 & -18.55 & 4.56 & -88.38 & -8.02 \\
\hline EBT Margin & 21.52 & 5.15 & 9.63 & -26.48 & 7.73 & 88.37 & 17.65 \\
\hline ROE & 1.67 & 1.90 & 8.85 & -98.98 & 39.27 & 367.02 & 53.29 \\
\hline ROA & 2.00 & 2.26 & 11.90 & -35.33 & 11.79 & -249.30 & -42.78 \\
\hline Liquidity ratio & & & & & & & \\
\hline Financial Structure ratio (in \%) & & & & & & & \\
\hline Equity to Total Liabilities Ratio & 169.48 & 14.7 & 17.98 & 40.07 & 55.81 & 70.35 & 61.40 \\
\hline Source Pursent
\end{tabular}

Source: Published Annual Financial Statements \& Own calculations.

Table 3 reports the outcomes of the calculation of financial ratios, regarding HOP's profitability, liquidity and financial structure. Among the margins, the gross profit and the EBT exhibited a positive value on average, reaching 43.68 percent and 17.65 percent respectively. Regarding the EBITDA margin, the results are mixed as in 2004 HOP experienced the highest positive value (31.89 percent) and in 2009 it appeared to have the lowest one (-88.38 percent).

Ratios of returns on invested capital are among the key measurements revealing the attractiveness of the industry for capital investments (Philippatos and Athanasopoulos 1985). Good ratios attract new funds from ambitious entrepreneurs, whereas bad ratios condemn the industry in gradual decay (Niarchos 2004). In this analysis we use the ROE and ROA ratio measuring the return on equity investments and assets respectively. HOP exhibited a positive and high enough ROE (53.29 percent) on average, while ROA accounted for 42.78 percent on average for the same period.

The liquidity of HOP is measured by the current ratio. The current ratio is highly monitored by the financial institutions lending money. The calculation is based on a comparison between current assets and current liabilities. We generally look for a value comfortably in excess of 1.0 for this ratio. In Table 3 we observe that in 2004 HOP displayed the highest current ratio (2.69), while the lowest current ratio (0.26) is reported in 2009. The overall average for the period 2004-2009 is 1.45 .

The analysis of a HOP's financial structure is important in order to evaluate whether it is over or under leveraged in terms of financial indebtedness. Note that the nature of HOP owning and operating high-value properties, easily pledged as collateral for loan advances, justifies higher than usual financial leverage. Performing the financial structure analysis by examining the ratio of Equity to Total Liabilities, a value of 61.40 is found indicating a relatively low financial leverage. 


\section{Conclusions and Policy Implications}

For modern city seeking global recognition and status, the Olympic games offer a unique opportunity to present itself dynamically on the world stage. By bidding for the Olympics the host city aspires to boost its economy by promoting itself in the global tourism market, upgrading urban areas and transport infrastructure and creating modern venues that could also provide a basis for future bids. The ambitions of Athens included all aforementioned.

Looking at the Greek Olympic games it seems that there had been inadequate attention paid to planning for the post-games period and its legacy. Athens focused heavily on winning the bid, building the infrastructure and staging successful games that the post-games period was neglected. In a public opinion poll held four years after the games and on the accession of the Beijing Olympics, Greek citizens were asked to declare whether they believed their government had taken advantage of the Athens games. Eight out of ten citizens answered that they thought their government had failed to take advantage of the games' success. However, strong feelings of pride and nostalgia for the Athens games, which were regarded as a great success, were also evident. According to the survey the majority of the citizens polled believed that the games had benefited the country in general and Athens in particular, although the government had not taken advantage of the games, resulting in a missed opportunity (Kotrotsos 2008). More importantly and unanimously with the results of 2004 public opinion, the majority of respondents believed the 2004 Olympics were worthwhile despite the huge cost and failure to immediately exploit the opportunities the games had offered.

Athens city did achieve the realization of some of its aspirations; others, however, still wait the date of their partial or full realization. This happened because there was not a plan for the immediate post-games period on what should be done with the games infrastructure, particularly the new venues created for the games. HOP, the government-controlled organisation responsible for making use of each of the Olympic venues after the games was extremely slow and inefficient in the utilization of its assets, while its annual published financial statements revealed negative bottom lines. More attention was needed to be paid as to i) whether there could be some ongoing return and community benefit from Olympic precincts and venues and ii) whether to maintain state of the art Olympic venues after the games and, if so, making them cost effective.

To the extent that all those facilities did not have a meaningful post-games use they became "white elephants" burdening the Greek taxpayers, and partly accused of causing the current economic crisis. As most European countries were coming out of recession at the end of 2009, Greece was entering a tumultuous period. The slowdown in global economic activity in 2008, and the recession in OECD countries in 2009 were the prelude, but not the cause, of the Greek crisis. When the global financial crisis struck, Greece was badly prepared after years of profligacy, hosting an expensive Olympic games in 2004 , and failing to rein in its spiraling public debt. While many factors were 
behind Greece's debt crisis, the steep rise in spending on infrastructure necessitated by the 2004 Athens Olympics has drawn particular attention. If not the sole reason for the country's financial mess, some point to the games as at least an illustration of what has gone wrong in Greece. No doubt, the spectacle of modern, expensive Olympic assets in a state of disrepair is at least disappointing and understandably provokes the indignation of the Greek people, who have paid dearly and will long continue paying for these facilities.

\section{References}

Balfousia-Savva S, Athanassiou L, Zaragas L, Milonas A (2001) The Economic Effects of the Athens Olympic Games. Centre of Planning and Economic Research, Athens: KEPE.

Beriatos E, Gospodini A (2004) "Glocalising" Urban Landscapes: Athens and the 2004 Olympics. Cities 21(3): 187-202.

Frantzeskakis J, Frantzeskakis M (2006) Athens 2004 Olympic Games: Transportation Planning Circulation and Traffic Management. ITE Journal 76(10): 26-32.

Galpin R (2005, 30 March) Greece lays out post-Olympic plan. BBC News.

Hellenic Government Gazette (2005) Government Gazette Issue No (FEK) 131/A/06.06.05 (in Greek).

Hellenic Olympic Properties (2006) Press release 15.05.06.

Hellenic Olympic Properties (2008) Press releases 13.09.08, 15.09.08, 28.11.08.

Kasimati E, Dawson P (2009) Assessing the impact of the 2004 Olympic Games on the Greek economy: A small macroeconometric model. Economic Modelling 26(1): 139-146.

Kasimati E (2008) Macroeconomic and Financial Analysis of Mega-Events: Modelling and Estimating the Impact of the 2004 Summer Olympic Games in Greece. Saarbrucken: VDM Verlag.

Kasimati E (2003) Economic aspects and the summer Olympics: a review of the related research. International Journal of Tourism Research 5(6): 433-444.

Kathimerini (2008, 8 August) Life after the Games. p. 10 (in Greek).

Kissoudi P (2010) Athens' post-Olympic aspirations and the extent of their realization. The International Journal of the History of Sport 27(16-18): 2780-2797.

Kissoudi P (2008) The Athens Olympics: optimistic legacies - post-Olympic assets and the struggle for their realization. The International Journal of the History of Sport 25(14): 1972-1990.

Kotrotsos P (2008, 10 August) From national pride to regret of missed opportunity. Eleftheros Typos.

Milionis S (2010) City marketing in Greece: the post-Olympic use of Hellinikon former airport site. Regional Science Inquiry Journal 2(2): 151-172.

Niarchos N (2004) Economic Analysis of Financial Statements ( $7^{\text {th }}$ Edn.). Athens: Stamoulis Publications (in Greek).

Noll RG, Zimbalist A (1997) Sports, Jobs and Taxes: the Economic Impact of Sports Teams and Stadiums. Washington, DC: Brookings Institution Press.

Papanikos G (1999) Tourism Impact of the 2004 Olympic Games. Athens: Tourism Research Institute (In Greek).

Philippatos G, Athanasopoulos P (1985) Introduction to Financial Management. Athens: Papazisis publications (in Greek). 
Vol. 2, No. $3 \quad$ Kasimati: Post-Olympic Use of the Olympic Venues: The Case of Greece

Preuss H (2004) The Economics of Staging the Olympics: A Comparison of the Games 1972-2008. United Kingdom: Edward Elgar.

Siegfried J, Zimbalist A (2000) The Economics of Sports Facilities and their Communities. Journal of Economic Perspectives 14(3): 95-114.

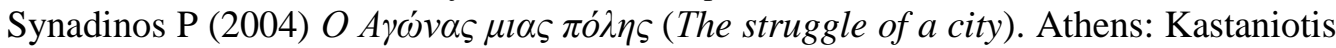
publications (in Greek).

Veraros N, Kasimati E, Dawson P (2004) The 2004 Olympic Games announcement and its effect on the Athens and Milan stock exchanges. Applied Economics Letters 11(12) 749-753.

Walsh C (2005) Key Management Ratios: The Clearest Guide to the Critical Numbers that Drive your Business ( ${ }^{\text {th }}$ Edn.). London: Financial Times/Prentice.

Weston JF, Brigham EF (1986) Basic Principles of Financial Management and Policy. Athens: Papazisis publications (in Greek). 